\title{
Size, efficiency, market power, and economies of scale in the African banking sector
}

\author{
Simplice A. Asongu ${ }^{1,2^{*}}$ and Nicholas M. Odhiambo ${ }^{1}$
}

\author{
* Correspondence: \\ asongusimplice@yahoo.com; \\ asongus@afridev.org \\ 'Department of Economics, \\ University of South Africa, P. O. Box \\ 392, Pretoria 0003, South Africa \\ ${ }^{2}$ Department of Economics \& \\ Development Studies, Covenant \\ University, Ota, Nigeria
}

\begin{abstract}
There is a growing body of evidence that interest rate spreads in Africa are higher for big banks compared to small banks. One concern is that big banks might be using their market power to charge higher lending rates as they become larger, more efficient, and unchallenged. In contrast, several studies found that when bank size increases beyond certain thresholds, diseconomies of scale are introduced that lead to inefficiency. In that case, we also would expect to see widened interest margins. This study examines the connection between bank size and efficiency to understand whether that relationship is influenced by exploitation of market power or economies of scale. Using a panel of 162 African banks for 2001-2011, we analyzed the empirical data using instrumental variables and fixed effects regressions, with overlapping and non-overlapping thresholds for bank size. We found two key results. First, bank size increases bank interest rate margins with an inverted U-shaped nexus. Second, market power and economies of scale do not increase or decrease the interest rate margins significantly. The main policy implication is that interest rate margins cannot be elucidated by either market power or economies of scale. Other implications are discussed.
\end{abstract}

Keywords: Sub-Saharan Africa, Banks, Lending rates, Efficiency, Quiet life hypothesis, Competition

JEL classifications: E42, E52, E58, G21, G28

\section{Introduction}

Over the decade since the 2008 financial crisis, the literature on banking and finance has seen renewed interest in a number of areas, including the nexus between loan growth, regulation, diversification, and competition, and the development indicators for risk, capital management, and efficiency of banks (Kashif et al. 2016; Bokpin 2016; Fanta 2016; Zheng et al. 2017; Ozili 2017; Khraisha and Arthur 2018). Interest has also grown regarding banking industry performance in terms of allocation efficiency, risk management and profitability (Moudud-Ul-Huq 2017; Hamdi et al. 2018), the application of manifold learning approaches (Huang and Kou 2014; Yan et al. 2017), and the implications of Basel III for banking sector development (Ramlall and Mamode 2017).

Financial intermediation represents the fundamental mission of banks to mobilize deposits into credit for economic operators. This paper was motivated by two main

(c) The Author(s). 2019 Open Access This article is distributed under the terms of the Creative Commons Attribution 4.0 International License (http://creativecommons.org/licenses/by/4.0/), which permits unrestricted use, distribution, and reproduction in any medium, provided you give appropriate credit to the original author(s) and the source, provide a link to the Creative Commons license, and indicate if changes were made. 
considerations in scholarly and policy circles: (1) the ongoing debate about the relationship between bank size and the efficiency of financial intermediation, and (2) gaps in the existing literature regarding this subject. Questions about the role of bank size in improving efficiency in the banking sector are reflected in the work of various researchers, including Asongu et al. (2016); Boateng et al. (2018), and Asongu and Odhiambo (2018). Existing research maintains that some big banks might abuse their market power instead of leveraging economies of scale to increase their efficiency in financial intermediation. The mechanisms for enhancing financial intermediation include, inter alia, increasing the quantity of loans, decreasing the price of loans (i.e., interest rates and fees), and reducing information asymmetry between borrowers and lenders (Kusi et al. 2017; Kusi and Opoku Mensah 2018; Tchamyou 2018a, b).

There is a growing body of evidence that for big banks in Africa, interest rate spreads are higher as compared to small banks (Beck and Hesse 2006; Ahokpossi 2013). ${ }^{1}$ Interest rate spreads have been used widely in the literature to indicate the level of banking sector efficiency (Dabla-Norris and Floerkemeier 2007; Chortareas et al. 2012; Asongu 2017). Big banks are expected to have lower margins because they have more opportunities to leverage their size to achieve economies of scale. This capacity for leverage should allow the larger banks to benefit from lower funding costs compared to the smaller banks. Therefore, it would be reasonable to surmise that one of the main benefits of bigger size would be gains in efficiency that transfer to the banks' customers through higher deposit rates, lower lending rates, and lower overall interest spreads. However, research indicates that this expectation is not being met. Big banks worldwide continue to be more inefficient than their smaller counterparts, which is a paradox (Mitchell and Onvural 1996; Karray and Chichti 2013; Asongu et al. 2018a; Asongu and Biekpe 2018). ${ }^{2}$ Therefore, concerns are emerging about the role of bank size in improving efficiency in the banking sector (Karray and Chichti 2013).

Two arguments have been put forward that attempt to explain this paradox. The first view holds that as big banks become bigger, more efficient, and unchallenged, they tend to abuse their power to exploit customers by creating monopolistic practices (Mitchell and Onvural 1996). The second argument is that increased bank size beyond certain thresholds introduces diseconomies of scale that in turn lead to inefficiency. According to this view, larger banks find themselves with higher and higher average costs as they grow beyond a crucial threshold, and these costs lead to wider interest margins and inefficiency (Berger et al. 1987; Noulas et al. 1990; Mester 1992; Clark 1996; Karray and Chichti 2013). ${ }^{3}$ In other words, contrary to expectations, increased size beyond the identified threshold would widen interest margins to the detriment of customers.

In the light of the above, the problem to be addressed can be stated as follows: "Is the relationship between bank size and efficiency influenced by exploitation of market power or economies of scale?" To the best of our knowledge, the existing literature regarding African financial development has not focused on this underlying question for banks. ${ }^{4}$ This paper contributes to the literature by providing a deep examination of the connection between bank size and efficiency in Africa, with the concurrent goal of determining whether that association is influenced by abuse of market power or economies of scale. For this research, we used a panel of 162 African banks with data for 2001-2011, and we analyzed the empirical evidence using instrumental variables and fixed effects regressions. Our research provided two key results. First, we found 
that bank size increases the interest rate margins enjoyed by a bank, following an inverted U-shaped curve. Second, market power and economies of scale do not increase or decrease the interest rate margins significantly. The main policy implication is that interest rate margins cannot be elucidated by market power or economies of scale.

The remainder of this paper is organized as follows. Literature review and clarification of concepts section provides a review of the related literature and clarification of the concepts used in this work. Bank size, market power, and efficiency section presents our data and methodology, and the empirical results are given in Economies and efficiency in the banking industry section. Cost efficiency section provides our conclusion, including the implications of our findings and suggestions for future research.

\section{Literature review and clarification of concepts}

Bank size, market power, and efficiency

An examination of the existing literature reveals that there is no consensus about the relationship between bank size, market power, and efficiency. The research findings about the direction of the possible effects are subtle and sometimes ambiguous at best. In this section of the paper, we take a detailed look at the prior literature and the concepts related to our two lines of consideration: first, the relationship between bank size and efficiency, and second, the nexus between market power and efficiency.

From an intuitive standpoint, we would expect to find a positive relationship between bank size and efficiency because larger banks are more likely to develop technical, financial, material, and human resources that enhance efficiency. However, since problems connected to agency, coordination, and other dysfunctionalities are more apparent in larger firms, we might expect their smaller counterparts to generate relatively higher efficiency scores. ${ }^{5}$ In addition to the U-shaped curve mentioned above, there is empirical evidence regarding economies of scale in the banking industry. Berger and Mester (1997) found that while bigger banks were slightly more cost effective, smaller banks were more cost efficient. Their results demonstrated that with increasing size, the banks studied were more able to increase control over costs, but they found it more difficult to generate income and profit efficiently. This position was shared by Srivastava (1999), who found higher average efficiencies for medium-sized banks, followed by large banks. The finding that small banks were the least efficient confirmed the position that the nexus between these factors is not positively monotonic. No clear relationship between efficiencies and size has been established in the wealth of literature (Fukuyama 1993; Lang and Welzel 1996; Altunbas et al. 2000; Karray and Chichti 2013; Goldberg and Rai 1996; and Allen and Rai 1996), which both negates and supports the hypothesis that larger banks are associated with higher levels of inefficiency.

Empirical investigation of the connection between market power and efficiency has included testing the Quiet Life Hypothesis (QLH). This view suggests that firms enjoy the advantages of market power in terms of forgone revenues and cost savings. According to this hypothesis, firms with higher market power put less effort into pursuing cost and profit efficiencies. Instead of leveraging their size to cut costs and increase intermediation efficiency, large banks prefer to enjoy a "quiet life" or the "exploitation of market power" to reap higher profit margins (Hicks 1935; Maudos and De Guevara 2007; Koetter and Vins 2008; Coccorese and Pellecchia 2010; Asongu and Nwachukwu 2018). 


\section{Economies and efficiency in the banking industry}

In this part of the paper, we examine the seven economies of banking in terms of five main considerations: cost efficiency, revenue efficiency, captivity efficiency, concentration efficiency, and the view that includes Xefficiency, scale efficiency, and scope efficiency.

\section{Cost efficiency}

Many authors have argued that size brings economies of scale and accompanying cost reductions (Mitchell and Onvural 1996; Karray and Chichti 2013). This view is based on the belief that unavoidable costs, such as branding, commercial networks, information and communication technology (ICT), and regulatory expenses, are more easily absorbed through large volumes of business. However, as highlighted earlier, the literature has instead documented a U-shaped nexus between bank size and the unit costs of banks. Moreover, large banks appear to work with more advanced technology, which potentially limits their economies of scale.

\section{Revenue efficiency}

Consistent with De Keuleneer and Leszczynska (2012), revenue efficiency is determined by bank-specific factors or other independent variables rather than bank size. There is a threefold intuition motivating this line of thought. (1) Very large corporations use banks of all sizes, provided that the banks offer good services. Hence, the idea that large corporations request extensive privileges as a condition for dealing with a bank (or conversely, that large clients are the most profitable and loyal) is not always accurate. (2) It may be claimed that banks with large international networks can offer superior services. However, a good network of correspondent banks can offer services equivalent, or even superior, to a proprietary network whose foreign branches might be insignificant locally and of little added value. (3) Whereas better diversification of risk is also mentioned by advocates of large banks, risk diversification can be achieved in various ways, notably through credit syndications and various credit insurance mechanisms (Tchamyou et al. 2018).

\section{Captivity efficiency}

In accordance with De Keuleneer and Leszczynska (2012), captivity efficiency focuses on the ambitions of large continental banks that aim to increase their control over the distribution of financial products. While controlling their investments according to the directive on Undertakings for Collective Investment in Transferable Securities (UCITS), these banks also underwrite all kinds of structured products that they distribute, leaving little choice to the clients they claim to advise. In so doing, they disclose little information to allow for transparent competition. Size procures an advantage in this kind of abuse.

\section{Concentration efficiency}

The concept of concentration efficiency reflects the finding that many bankers still pursue size as an objective in spite of the lack of a proven nexus between size and efficiency or size and profitability (De Keuleneer and Leszczynska 2012). Advocates of 
this idea note that relative size within a market is useful because market concentration is rather well-correlated with higher profitability. Banking sectors with a higher degree of concentration enable banks to charge higher margins, which justifies higher remunerations for managers.

\section{$X$-efficiency, scale efficiency, and scope efficiency}

In line with Wagenvoort and Schure (1999), this view holds that when assessing efficiency, a researcher should be interested in X-efficiency (whether banks use their available inputs efficiently), scale efficiency (whether banks produce the right amount of outputs), and scope efficiency (whether banks choose an efficient combination of outputs).

\section{Measurements}

In this section, we discuss measures of market power and bank size, and indicators of efficiency and economies of scale. In the banking literature, market power is measured primarily with the Lerner index (Ariss 2010; Asongu et al. 2018b). This indicator measures the extent to which a bank can set prices above its marginal costs. An increase in the Lerner index is associated with greater market power. Two measures of bank size have been used predominantly in the literature: systemic and absolute bank size. Systemic bank size is measured either as the ratio of gross income to GDP (Demirgüç-Kunt and Harry 2011) or bank assets as a percentage of GDP. A bank's absolute size may be defined as the log of total assets (Demirgüç-Kunt and Harry 2011) or the ratio of bank total assets to total financial system assets (Beck et al. 1999).

Of the five categories of efficiencies described in Section 2.2 above, the concepts of captivity and concentration efficiencies are not widely used in the empirical literature. Hence, we consider the other three main themes: revenue efficiency, cost efficiency, and economies of scale. ${ }^{6}$ As we have already highlighted above, interest rate spreads are used to measure banking sector profit efficiency (Dabla-Norris and Floerkemeier 2007; Chortareas et al. 2012). Profit efficiency scores from the trans$\log$ profit function are also indicators for revenue efficiency in the mainstream banking literature (Koetter and Vins 2008; Ariss 2010). Cost efficiency is measured with cost efficiency scores from the translog cost function (Koetter and Vins 2008; Ariss 2010; Coccorese and Pellecchia 2010).

Economies of scale (ES) may be measured using various asset size classes (Wagenvoort and Schure 1999). Dummy variables are then assigned to these asset classes and used as independent variables in the cost equation. Returns to scale (RS) are appreciated based on parameter estimates. While Wagenvoort and Schure (1999) employed a Cobb-Douglas cost function, we use the translog to overcome some of the restrictive properties of the Cobb-Douglas approach, namely single product output and a log-linear cost curve. Consistent with Brown and O'Connor (1995 pp.7-8), from a translog cost function, ES is measured by the sum of the derivations in the cost equation with respect to output. A sum equal to one denotes constant RS, whereas a sum less (or greater) than one represents increasing (decreasing) RS. Accordingly, within the framework of this study, the ES variable is the sum of the derivation of Cost $(\ln C)$ with respect to Output or Loans $(\operatorname{LnQ})$. 


\section{Methodology and data}

Methodology

Empirical estimation of market power (Lerner index), economies of scale, and bank size

Due to the panel structure of our dataset, we employ the stochastic frontier model of Battese and Coelli (1992) to estimate time varying cost efficiency scores. Consistent with Coccorese and Pellecchia (2010), this model presents some advantages in comparison with other approaches, especially those based on deterministic frontiers (Farrell 1957; Aigner and Chu 1968). The Battese and Coelli model accounts for the possibility that the deviation between the observed output and the frontier output could result from other factors, such as stochastic shocks and measurement errors, in addition to the firm's own inefficiency.

Let us assume that, for firm $i$ at time $t$, production costs are a function of output (Q), input prices $(W)$, inefficiency $(u)$, and random error $(v)$. With the last two terms independent and identically distributed (iid), the logarithmic specification of the cost function can be written as follows:

$$
\ln C_{i t}=f\left(Q_{i t}, W_{i t}\right)+v_{i t}+u_{i t},
$$

where the error term and non-negative inefficiency terms are iid, following a normal distribution and a truncated normal distribution respectively. Hence, while $v_{i t}$ is $N\left(0, \sigma_{v}{ }^{2}\right), u_{i t}$ is $N\left(\mu, \sigma_{u}{ }^{2}\right)$.

To model the cost, we use a translog function with three inputs and one output. This function, which was first proposed by Christensen et al. (1971) and then extended to a multiproduct framework, has been employed frequently for the assessment of the QLH in the banking literature (Koetter and Vins 2008; Coccorese and Pellecchia 2010; Ariss 2010; Asongu and Odhiambo 2018). The cost function is as follows:

$$
\begin{aligned}
\ln C_{i t}= & \alpha_{0}+\alpha_{1} \ln Q_{i t}+\sum_{h=1}^{3} \alpha_{h} \ln W_{h i t} \\
& +\frac{1}{2}\left\{\alpha_{Q Q}\left(\ln Q_{i t}\right)^{2}+\sum_{h=1}^{3} \sum_{k=1}^{3} \alpha_{h k} \ln W_{h i t} \ln W_{k i t}\right\} \\
& +\sum_{h=1}^{3} \alpha_{Q h} \ln Q_{i t} \ln W_{h i t}+v_{i t}+u_{i t}
\end{aligned}
$$

where $i=1, \ldots \ldots . . . N$ and $t=1 \ldots \ldots \ldots . . . T$ denote index banks and time, respectively. $C$ is the total cost, $Q$ is the output, $W h$ are factor prices, while it $u$ and $i t v$ are the error and inefficiency terms, respectively.

$$
\begin{aligned}
& M C_{i t}=\frac{\partial C_{i t}}{\partial Q_{i t}}=\frac{\partial \ln C_{i t}\left(C_{i t}\right)}{\partial \ln Q_{i t}\left(Q_{i t}\right)}=\left(\alpha_{Q}+\alpha_{Q Q} \ln Q_{i t}+\sum_{h=1}^{3} \alpha_{Q h} \ln W_{h i t}\right) \frac{C_{i t}}{Q_{i t}} \\
& \text { LERNER }_{i t}=\frac{P_{i t}-M C_{i t}}{P_{i t}}
\end{aligned}
$$

where $P$ it is the price charged by a bank for its output. In theory, the Lerner index can vary between 0 (in the case of perfect competition) and 1 . As discussed in the preceding section (regarding the translog cost function), ES is measured by the 
sum of the derivations in the cost equation with respect to output (Brown and O'Connor 1995).

$$
E S_{i t}=\frac{\partial C_{i t}}{\partial Q_{i t}}=\alpha_{1}+\alpha_{Q Q} \ln Q_{i t}+\sum_{h=1}^{3} \alpha_{Q h} \ln W_{h i t}
$$

Due to the constraints in the measurement of systemic bank size, we employ the absolute bank size measurement in this study. The \% GDP-based bank size measurements are too small to produce summary statistics values that are comparable with other variables. Consequently, for the absolute bank size measurement for a given bank at a given period, we adopt the ratio of bank assets to total assets (bank assets plus other banks' assets) for a given period in a given country (Beck et al. 1999). It is also interesting to note that we cannot use the logarithm of bank assets (Demirgüç-Kunt and Harry 2011, p. 6) because of differences in measurement (i.e., local currency) units. For the absolute bank size measurement, we use both overlapping (size $<0.25$, size $<0.50$, size $<0.75$ ) and non-overlapping thresholds ${ }^{7}$ (Wagenvoort and Schure 1999). While only the results of the former are disclosed, the latter is used for robustness purposes.

\section{Testing the underlying "quiet life hypothesis" (QLH)}

Given the focus of this research, testing the underlying hypothesis (i.e., the QLH) consists of assessing whether increasing the bank size beyond a certain threshold increases interest rate margins to the detriment of customers. To this end, for various asset classes (with overlapping and non-overlapping thresholds), we regressed the interest margin on the computed bank size, controlling for market- and bank-level variables as well as the unobserved heterogeneity and endogeneity.

To tackle the additional aspect of the problem addressed in this paper, we examined whether bank inefficiency resulting from the QLH hypothesis is the result of abuse of power or economies of scale. Hence, for the same asset classes (overlapping and non-overlapping) used in testing the underlying hypothesis, the $\mathrm{QLH}^{8}$ test was implemented for African banks by regressing the interest rate margin on the estimated Lerner index (LERNER), ES, and on a set of market- and bank-level variables (controlled for the unobserved heterogeneity and endogeneity). A positive and statistically significant estimate of the variable corresponding to LERNER can be interpreted as evidence of the validity of the QLH. However, if the estimated coefficient corresponding to the ES variable increases (decreases) significantly with an improvement in asset classes, then inefficiency (efficiency) is attributable to ES.

To tackle any issues of endogeneity that might arise, the LERNER, ES, and bank size variables were instrumented with their first lagged values. Accordingly, the LERNER variable could be endogenous because the efficiency structure hypothesis postulated a causal connection from efficiency to market power, ES, and bank size.

\section{Data}

To estimate the cost function, we specified one output and three inputs. Total operating cost was measured with overhead, output by total assets, and input by the price of deposits, price of labor, and price of capital. ${ }^{9}$ The Lerner index was computed from the price and marginal cost (see Eq. (4)). While the marginal cost was computed from the 
translog cost function output (see Eq. (3) and Appendix 4), the price was given as the price charged by banks for their output (total assets), computed as the ratio between total revenues (interest income plus net noninterest income) and total assets. ES was computed from Eq. (5).

We controlled for bank-level and market-oriented characteristics. The bank-level variables included the following.

(1) Ratio of loans to total assets: In contrast to other bank assets, such as securities, lending requires more organizational capabilities and effort by the staff. Hence, if not properly performed, lending could generate inefficiencies.

(2) Ratio of deposits to assets: While deposits are the main source of funds for banks, they also require good organization in order to be mobilized and well managed. Therefore, a higher proportion of deposits to liabilities could increase interest margins.

(3) Number of bank branches: The number of branch banks is an essential consideration because a widespread branch network entails the creation and management of a retail organization. This effort could have either a negative or positive effect on cost efficiency. While we expect positive coefficients from the first two bank-level variables listed above for the reasons discussed, this third variable could have a negative or positive effect on interest margins depending on the coordination and organization of problems and opportunities linked to a bigger branch network. Therefore, the number of bank branches could also be a proxy for bank size.

Next, we controlled for three main market variables: GDP growth, population density, and inflation.

(1) The GDP growth rate was included to take into account the influence of business cycle fluctuations on efficiency. For instance, in dynamic and expanding markets, banks may benefit from growing demand, increased activity in branch offices, and expanded networking that could improve efficiency as a result. However, while exploiting the opportunities for short-run profitability, banks also might forgo efficiency. Consequently, the expected sign (positive or negative) cannot be anticipated with certainty.

(2) The positive or negative impact of population density is also uncertain. In markets of high population density, it should be less costly to offer banking services. However, dealing with more customers could generate inefficiencies because of the need to meet all of their diverse requirements.

(3) Intuitively, inflation should increase inefficiencies because of the risks associated with uncertainties. This expectation is consistent with evidence that inflation increases interest rates margins in SSA (Ahokpossi 2013, p. 19).

For this paper, our research sample consisted of 162 African banks from the Bankscope database for the period 2001-2011. In the Appendices, we present the summary statistics, correlation analysis (showing the relationships among key variables used in the paper), definitions of variables and their corresponding sources, and estimates of the cost function. From the summary statistics (Appendix 1), we can infer 
that there was a sufficient degree of variation in the data to allow confidence that reasonable estimated connections would emerge. The objective of the correlation analysis (Appendix 2) was to mitigate issues of multicollinearity, and from an initial assessment, there were no concerns in terms of the relationships to be estimated. There was no correlation higher than 0.500 , which is the rule of thumb for the absence of multicollinearity. The highest correlation coefficient was 0.350 . Moreover, the variance inflation factor was less than 10 (O'brien 2007). The definitions of variables (and corresponding sources) are provided in Appendix 3, while components of the cost function needed for the computation of marginal cost, the Lerner index, and ES are provided in Appendix 4.

\section{Empirical results}

Presentation of results

Table 1 presents our findings for the QLH, and Table 2 shows results for the main hypothesis. In both tables, Panel A is designed to control for unobserved heterogeneity, while Panel B is tailored to account for both observed heterogeneity and simultaneity. The first specification of each panel provides the baseline from which the effects of different asset thresholds are examined.

Table 1 assesses two main concerns related to the QLH, notably whether: (1) bank size generally increases financial intermediation inefficiency (or interest rate margins), and (2) increasing bank size beyond a certain threshold increases interest rate margins further, to the detriment of the customers. The estimated coefficients and information criteria for model validity were significant consistently across thresholds and panels for the first specifications exclusively. For this reason, the following presentation and discussion of results for Table 1 are restricted to this set of specifications.

From the weight of available empirical evidence, the following could be established. (1) The first part of the underlying hypothesis was confirmed because bank size significantly increased interest rate margins. (2) Concerning the second question, when we controlled for only unobserved heterogeneity (i.e., part of endogeneity), the second part of the QLH proved invalid because the increasing magnitude of larger banks across overlapping thresholds significantly mitigated the effect of bank size on interest rate margins (see Panel A). (3) When we accounted for endogeneity in the bank size measurement (see Panel B), there was evidence of an inverted U-shaped effect that validated the second part of the underlying hypothesis. In essence, while bank size increased interest rate margins from the first to the second threshold, the effect dropped from the second to the third threshold, reduced to a level almost similar to that of the first threshold. (4) The significant control variables had the expected signs. Population density had a positive effect because in markets of high population density, it is less costly to offer banking services. Improvement in GDP per capita growth does not necessarily translate into higher intermediary margins because economic prosperity in most of the sampled African countries has not been inclusive over the past decade (Chester 2010; Asongu and le Roux 2018), especially with respect to the longstanding issue of financial allocation efficiency (Asongu 2013). Accordingly, a majority of the elite that has benefited from this prosperity holds foreign bank accounts for obvious reasons. 


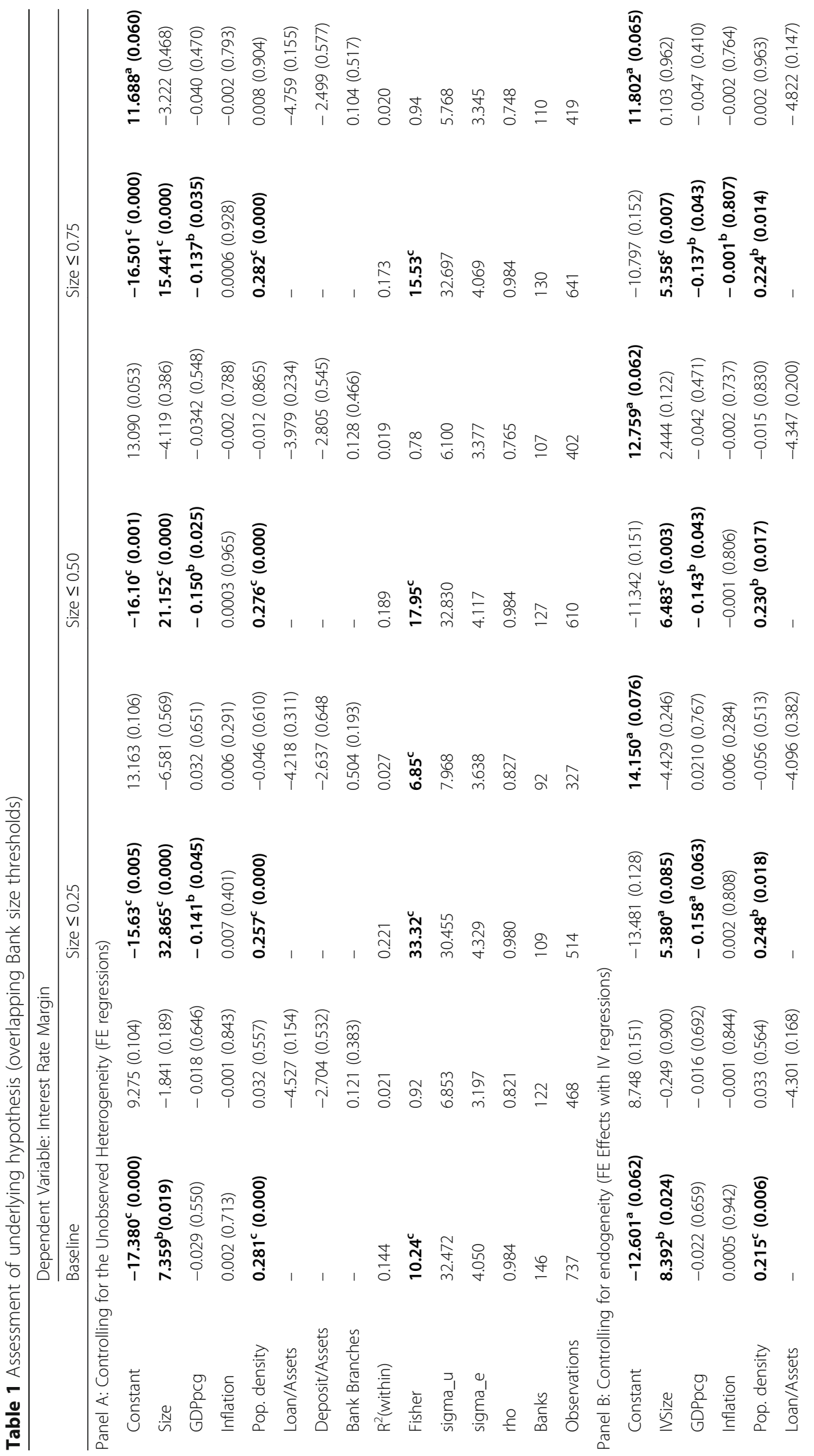




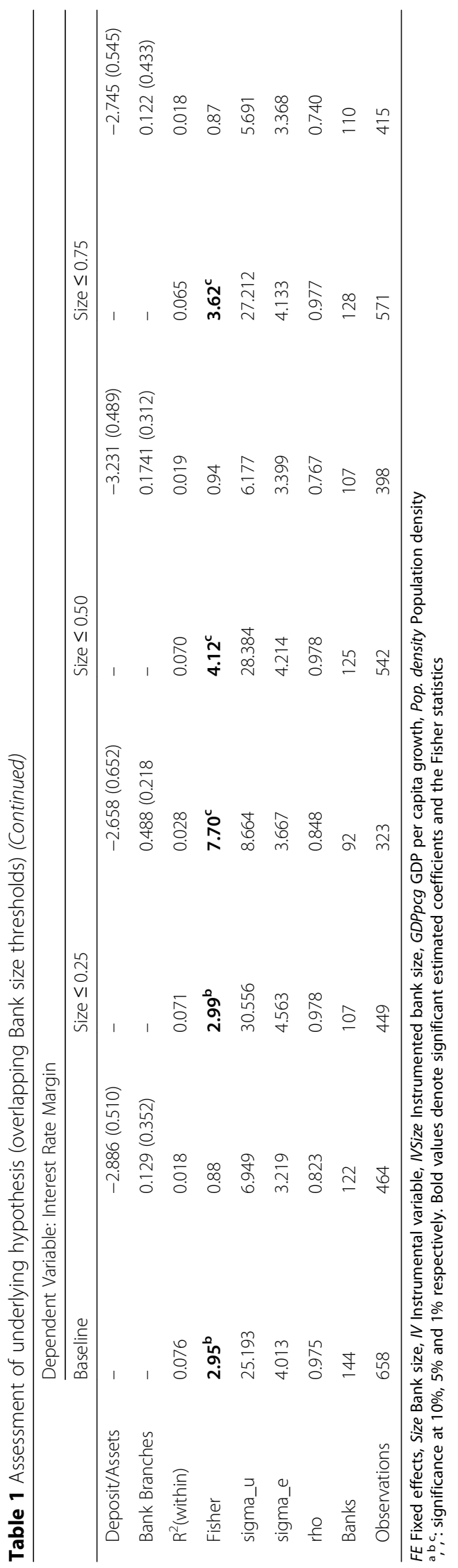




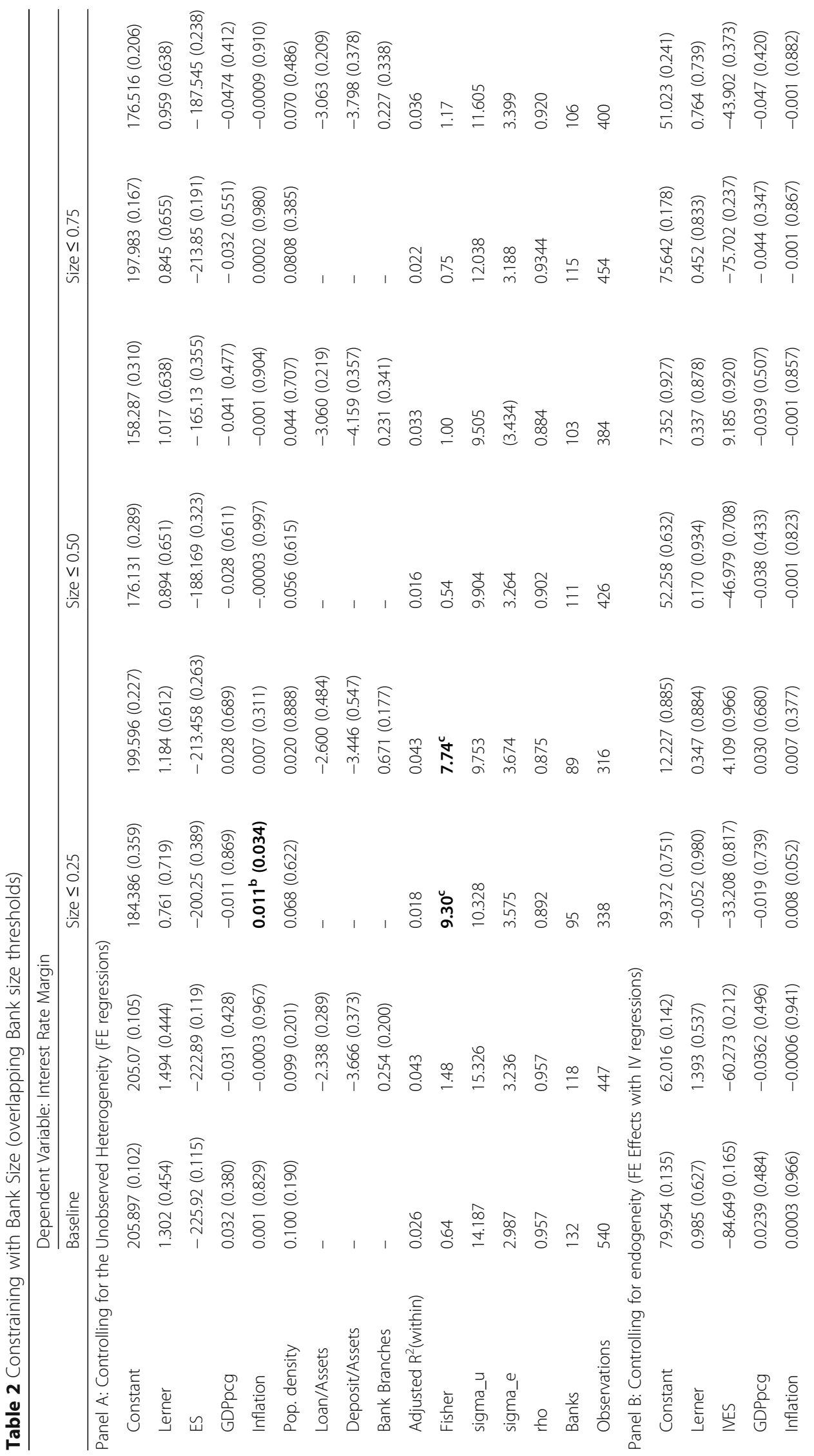




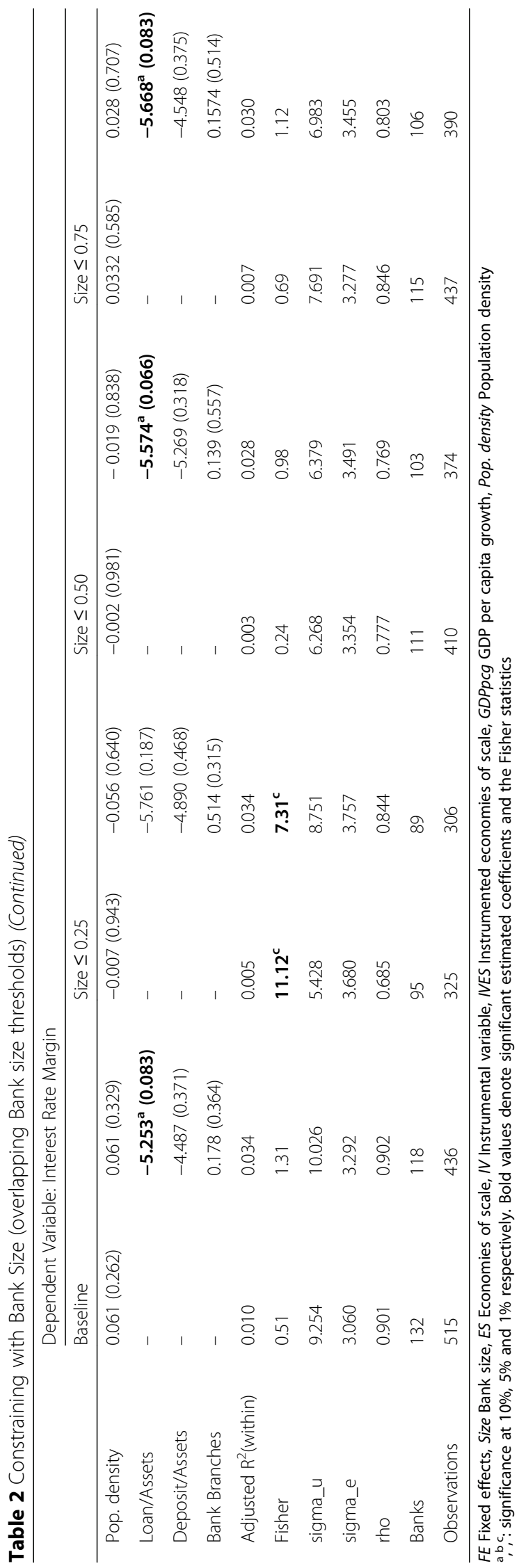


Given the demonstrated validity of the QLH, we proceeded to assess the second related question motivating the study: whether inefficiency is due to economies of scale or abuse of power. Unfortunately, for both panels of Table 2, the findings were not significant across the specifications, asset thresholds, and panels. Following the procedure used for Table 1, we replicated the analysis using non-overlapping thresholds, and found similar results. If statistical significance is overlooked, from the first threshold (i.e., Size $\leq 0.25$ ), increasing interest margins or intermediation inefficiency was traceable to market power (Lerner), ${ }^{10}$ while the category of economies of scale was a source of intermediation efficiency. It follows that other factors explain significant variations in interest rate margins besides market power and economies of scale.

\section{Further discussion and policy implications}

The following discussion of our findings proceeds in the light of the existing literature regarding bank size and efficiency, the QLH, and ES and efficiency. First, our results regarding the connection between bank size and efficiency were broadly consistent with the findings of Ahokpossi (2013, p. 1), who concluded that policies that promote competition and reduce market concentration help lower interest margins in SSA. Bank size contributed significantly to variations in bank spreads and margins (Beck and Hesse 2006, p. 1) since the high cost of loans was more favorable to big banks than small lenders (Ngigi 2013a, 2013b).

Second, while our findings regarding the Quiet Life Hypothesis were statistically insignificant, they confirmed the potential for applying the QLH in the African banking industry. This evidence broadly confirmed mainstream findings by $\mathrm{Tu}$ and Chen (2000) in Taiwan for 1986-1999, whose results were valid only before 1991; Koetter and Vins (2008) for Germany from 1996 to 2006, although the magnitude of the estimated effects of the QLH were small; Schaeck and Cihak (2008) for Europe and the USA from 1995 to 2005; Solis and Maudos (2008) regarding the loans market in Mexico for the years 1993-2005; Delis and Tsionas (2009) for Europe from 1996 to 2006, using a local maximum likelihood technique; Ariss (2010) in a sample of developing countries for cost efficiency; Coccorese and Pellecchia (2010) in Italy during 1992-2007, although the impact of market power on efficiency was not particularly remarkable in magnitude; and Asongu and Odhiambo (2018) in Africa.

Third, since the negative, although insignificant effect of ES may also be synonymous with the absence of market power, our findings also were broadly in accordance with studies that have not validated the QLH, including Weill (2004) in Europe for the years 1994-1999, who calibrated competition using the Panzar-Rosse H-statistic; Maudos and De Guevara (2007) for Europe from 1993 to 2002; Koetter et al. (2008) in the USA from 1986 to 2006; Pruteanu-Podpiera et al. (2008) who used Granger causality for their work regarding the Czech Republic from 1994 to 2005; Solis and Maudos (2008) for the deposits market in Mexico from 1993 to 2005; Al-Muharrami and Methews (2009) in the Arab Gulf from 1993 to 2002; Fu and Heffernan (2009) for China during 1985-2002; and Ariss (2010) for a sample of developing countries with respect to profit efficiency. 
It is vital to address the policy implications of the issues presented in this paper to ensure the soundness and regulation of the banking sector of Africa. The banking industry must have the capacity to serve the economy with a degree of competition that is sufficient in productivity to provide for its customers. Therefore, based on the weight of available empirical evidence, we recommend that regulatory and government policies should aim to meet the following objectives:

(1) Competition in the banking industry should be promoted in order to mitigate the potentially upward pressure of market power on interest margins to the detriment of customers.

(2) Market concentration should be discouraged because an increase in bank size is not associated with intermediation efficiency.

(3) Mergers and acquisitions should be discouraged if they lead to an increase in bank size beyond a mid-level threshold. This recommendation is based on the evidence found of an inverted $U$-shaped nexus in the relationship between bank size and inefficiency.

Moreover, because the banking sector is more concentrated in SSA than in the rest of the world (Ahokpossi 2013), policies designed to promote competition are important because they help to improve financial intermediation by lowering interest margins. However, given that markets tend to be small in SSA countries, the attendant policies should not focus exclusively on increasing the number of banks. Evidence indicates that increasing the number of banks within a small market framework to increase competition may not yield the desired outcome in Africa. The presence of a substantial number of financial institutions may not necessarily breed competition because there is a risk that banks may collude through channels such as bankers' associations. The promotion of competition will result most feasibly from better enforcement of antitrust laws in particular, and from encouragement of laws that promote competition in general. Proper regulation is also indispensable because size provides large banks with many commercial opportunities that can amount to outright corruption tools.

\section{Conclusion, caveats, and directions for future research}

There is a growing body of evidence indicating that interest rate spreads in Africa are higher for big banks compared to small banks. Interest rate spreads have been used widely in the banking literature to indicate the level of banking sector efficiency. It is indisputable that big banks have opportunities to leverage their size to benefit from lower funding costs based on economies of scale as compared to small banks. Therefore, we would expect that one of the main benefits of big size would be gains in efficiency that transfer to the banks' customers through higher deposit rates, lower lending rates, and lower overall interest spreads. However, this reduction in rates has not occurred. Therefore, questions are emerging about the role of bank size in improving efficiency in the banking sector.

One concern is that the big banks might be using their market power to charge higher lending rates as they become larger, more efficient, and unchallenged. However, several studies have found that increasing size beyond certain thresholds introduces diseconomies of scale that lead to inefficiency. Increased size beyond these thresholds 
would be expected to widen interest margins to the detriment of customers. Therefore, on the basis of these observations, the outlook for improving financial inclusion through mergers and consolidation is doubtful. The main question remains whether increased bank size is necessarily good for banking sector efficiency.

Using a panel of 162 African banks for the period 2001-2011, this study examined the connection between bank size and efficiency to understand whether the relationship is influenced by exploitation of market power or economies of scale. We analyzed the empirical evidence using instrumental variables and fixed effects regressions. The following findings were established. First, bank size increased the interest rate margins enjoyed by banks, with an inverted U-shaped nexus. Second, market power and economies of scale did not increase or decrease the interest rate margins significantly. The main policy implication is that the interest rate margins cannot be elucidated by market power or economies of scale.

The main caveat of this study is that our resulting policy recommendations are based on a broad sample of African countries that exhibit some significant heterogeneity. Future papers should aim to provide findings with more targeted country-specific implications. A step in this direction would be to place some emphasis on the legal origins of a country's civil laws in the light of the work by Muazu and Alagidede (2017), who examined the nexus between information asymmetry and financial development. In addition, it would be worthwhile to apply the updated methodology from Tsionas et al. (2018) to estimate the interplay between efficiency and market power. They have developed a unified econometric approach for the formal assessment of the relationship between market power and cost efficiency. Their technique can accommodate a mutually dependent connection between market power and a financial firm's cost efficiency. The framework allows for varying hierarchical orderings between a firm's efficiency and market power, and does not place any prior restrictions on the sign of the connection between the two.

In addition, improvements have been made in the computation of the Lerner index. A notable example is the stochastic frontier estimator of market power, an approach that can be used in both the primal framework and the dual cost function (Kumbhakar et al. 2012; Coccorese 2014; Anginer et al. 2014).

\section{Endnotes}

${ }^{1}$ Ahokpossi (2013, p. 1) concludes that policies that promote competition and reduce market concentration would help lower interest margins in sub-Saharan Africa (SSA). Beck and Hesse (2006, p.1) have also established that bank size significantly contributes to bank variation in spreads and margins. A case in point is the situation in Kenya where the high cost of loans is favorable to big banks over small lenders (Ngigi 2013a, 2013b).

${ }^{2}$ Karray and Chichti (2013) have recently assessed a panel of 402 commercial banks from 15 developing countries for the period 2000-2003 and found high levels of scale inefficiency among the largest banks.

${ }^{3}$ Consistent with Karray and Chichti (2013), a majority of studies have led to functions of estimated average cost with U-shaped profile. Accordingly, they decrease with size up to a certain value of total assets and unit costs rise beyond this level, indicating that it is the medium-sized banks that seem to have a more efficient scale than large and small banks. 
${ }^{4}$ Accordingly, the bulk of recent African financial development literature has not engaged the problem statement (Daniel 2017; Fowowe 2014; Wale and Makina 2017; Tchamyou and Asongu 2017; Chikalipah 2017; Bocher et al. 2017; Osah and Kyobe 2017; Obeng and Sakyi 2017; Ofori-Sasu et al. 2017; Chapoto and Aboagye 2017; Iyke and Odiambo 2017; Boadi et al. 2017; Triki and Gajigo 2014).

${ }^{5}$ Efficiency scores within the context of the study are based on cost efficiency, estimated with the translog cost function. The established association between bank size and efficiency is based on whether banks are fulfilling their fundamental mission of improving financial intermediation efficiency, notably: whether bank size generally increases financial intermediary inefficiency (or interest rate margins).

${ }^{6}$ Economies of scale and scale economies are used interchangeably throughout the study.

${ }^{7}$ Bank size $\leq 0.10 ; 0.10<$ Bank Size $\leq 0.25 ; 0.25<$ Bank Size $\leq 0.50 ; 0.50<$ Bank Size $\leq 0.75 ; 0.75<$ Bank Size $\leq 0.90 ; 0.90<$ Bank Size.

${ }^{8}$ Firms with higher market power put less effort in pursuing cost efficiency: instead of taking advantage of their favorable position by cutting costs, they prefer to enjoy a 'quiet life' or an exploitation of market power (Hicks 1935; Maudos and De Guevara 2007; Koetter and Vins 2008; Coccorese and Pellecchia 2010).

${ }^{9}$ The price of deposits is computed by dividing interest expenses by the sum of deposits, money market plus short term funding. The price of labor is defined as the ratio of personnel expenses to total assets. The price of capital is equal to the ratio of 'other operating costs' to the value of fixed assets.

${ }^{10}$ It should be noted that IVLerner is not used in Panel B of Table 2 because its explanatory power $\left(R^{2}\right)$ is very low after instrumentation with first lags and first differences. Accordingly, while IVLener is perfectly synonymous to Lerner, it has a low $R^{2}$.

\section{Appendix}

Table $\mathbf{3}$ Summary statistics

\begin{tabular}{lllllll}
\hline & & Mean & S.D & Minimum & Maximum & Observations \\
\hline Translog cost function variables & Ln. Cost (C) & 2.748 & 1.325 & -1.468 & 5.667 & 1065 \\
& Ln. Output (Q) & 3.747 & 1.342 & -0.045 & 6.438 & 1091 \\
& Deposit Price (W1) & 0.539 & 8.196 & 0.000 & 176.00 & 1031 \\
& Labour Price (W2) & 0.022 & 0.016 & 0.000 & 0.201 & 961 \\
& Capital Price (W3) & 1.733 & 3.884 & -0.074 & 72.750 & 1043 \\
Market variables & GDP per capita growth & 13.912 & 96.707 & -15.306 & 926.61 & 1782 \\
& Inflation & 10.239 & 22.695 & -9.823 & 325.00 & 1749 \\
Bank level variables & Population density & 81.098 & 106.06 & 2.085 & 633.52 & 1782 \\
& Loan/Assets & 0.449 & 0.183 & 0.000 & 0.966 & 1092 \\
& Deposits/Assets & 0.664 & 0.198 & 0.000 & 1.154 & 1052 \\
& Bank Branches & 6.112 & 6.158 & 0.383 & 37.209 & 1129 \\
Other variables & Output Price (P) & 0.338 & 0.929 & 0.000 & 25.931 & 1045 \\
& Interest Rate Margin & 3.804 & 5.534 & -23.620 & 27.310 & 1257 \\
& Lerner Index & 0.513 & 0.587 & -13.787 & 0.969 & 894 \\
& Bank Size & 0.264 & 0.334 & 0.000 & 1.000 & 1267 \\
& Economies of Scale & 0.915 & 0.017 & 0.867 & 0.950 & 1091 \\
\hline
\end{tabular}

Ln Logarithm, GDP Gross domestic product, S.D. Standard deviation 
Table 4 Correlation matrix

\begin{tabular}{lllllllllll}
\hline Lerner & GDPpcg & Infl. & Popden & L/A & D/A & B.Brchs & IRM & BkSize & ES & \\
\hline 1.000 & 0.002 & -0.001 & 0.011 & 0.099 & 0.054 & 0.046 & -0.171 & 0.016 & 0.083 & Lerner \\
& 1.000 & -0.034 & -0.081 & 0.030 & 0.048 & -0.057 & 0.033 & 0.077 & 0.029 & GDPpcg \\
& & 1.000 & -0.052 & -0.090 & 0.057 & -0.012 & 0.024 & -0.057 & 0.011 & Infl. \\
& & 1.000 & -0.014 & 0.126 & 0.350 & 0.062 & 0.008 & -0.119 & Popden \\
& & & 1.000 & -0.064 & 0.150 & -0.165 & 0.064 & 0.309 & L/A \\
& & & & 1.000 & 0.028 & 0.293 & 0.159 & 0.285 & D/A \\
& & & & & 1.000 & -0.149 & 0.086 & -0.157 & B.Brchs \\
& & & & & & 1.000 & 0.238 & 0.151 & IRM \\
& & & & & & & 1.000 & 0.321 & BkSize \\
& & & & & & & & & 1.000 & ES \\
\hline
\end{tabular}

Lerner Lerner index, GDPpcg GDP per capita growth, Popden Population density, L/A Loan on total assets, D/A Deposit on total assets, B. Brchs Bank branches, IRM Interest rate margin, BkSize Bank size, ES Economies of Sc

Table 5 Definitions of variables

\begin{tabular}{|c|c|c|c|}
\hline Variables & Signs & Definitions of variables & Sources \\
\hline Marginal Cost & $\mathrm{MC}$ & $\begin{array}{l}\text { The change in Total cost arising from a } \\
\text { change in Output by one unit. }\end{array}$ & Translog Cost Function \\
\hline Price (charged on Output) & $P$ & $\begin{array}{l}\text { (Gross Interest and Dividend income +Total } \\
\text { Non-Interest Operating Income)/Output }\end{array}$ & BankScope \\
\hline Lerner Index & Lerner & Firm's market power ((P-MC)/P) & Authors' calculation \\
\hline Cost & C & Total Operating Cost (Overheads) & BankScope \\
\hline Output & Q & Loans & BankScope \\
\hline Deposit Price & W1 & $\begin{array}{l}\text { Total Interest Expense/Total Deposits, Money } \\
\text { Market and Short-term Funding }\end{array}$ & BankScope \\
\hline Labour Price & W2 & Personnel Expenses on Total Assets & BankScope \\
\hline Capital Price & W3 & Other Operating Expenses on Fixed Assets & BankScope \\
\hline GDP per capita & GDPpcg & GDP per capita growth (annual \%) & WDI (World Bank) \\
\hline Inflation & Infl. & Consumer Price Index (annual \%) & WDI (World Bank) \\
\hline Populaton density & Popden & People per square kilometers of land area & WDI (World Bank) \\
\hline Loans/Assets & L/A & Loans on Total Assets & BankScope \\
\hline Deposits/Assets & $\mathrm{D} / \mathrm{A}$ & Deposits on Total Assets & BankScope \\
\hline Bank Branches & B. Brchs & $\begin{array}{l}\text { Number of Bank Branches (Commercial bank } \\
\text { branches per 100,000 adults) }\end{array}$ & BankScope \\
\hline Interest Rate Margin & IRM & $\begin{array}{l}\text { Difference between 'Interest Income on } \\
\text { Loans/Average Gross Loans' and 'Interest } \\
\text { Expense on Customer Deposits/Average } \\
\text { Customer Deposit' }\end{array}$ & BankScope \\
\hline Bank Size & BkSize & $\begin{array}{l}\text { Ratio of Bank Assets to Total Assets } \\
\text { (Assets in all Banks for a given period) }\end{array}$ & BankScope \\
\hline Economies of Scale & ES & $\begin{array}{l}\text { Sum of derivatives of the Cost function with } \\
\text { respect to Output. }\end{array}$ & Authors' calculation \\
\hline
\end{tabular}


Table 6 Estimates of the cost function

\begin{tabular}{llll}
\hline Parameters & Regressors & Coefficients & Standard Errors \\
\hline$a_{0}$ & Constant & $-0.2502^{\mathrm{b}}$ & 0.1358 \\
$a_{Q}$ & $\ln Q$ & $0.8683^{\mathrm{a}}$ & 0.0331 \\
$a_{1}$ & $\ln W_{1}$ & 0.0559 & 0.0623 \\
$a_{2}$ & $\ln W_{2}$ & $0.5919^{\mathrm{a}}$ & 0.1143 \\
$a_{3}$ & $\ln W_{3}$ & $0.2037^{\mathrm{a}}$ & 0.0557 \\
$a_{\mathrm{QQ}}$ & $(\ln Q)^{2} / 2$ & $0.0127^{\mathrm{c}}$ & 0.0067 \\
$a_{11}$ & $\left(\ln W_{1}\right)^{2} / 2$ & -0.0139 & 0.0242 \\
$a_{22}$ & $\left(\ln W_{2}\right)^{2} / 2$ & $-0.1034^{\mathrm{c}}$ & 0.0614 \\
$a_{33}$ & $\left(\ln W_{3}\right)^{2} / 2$ & $-0.0935^{\mathrm{a}}$ & 0.0262 \\
$a_{\mathrm{Q} 1}$ & $\ln Q \times \ln W_{1}$ & $-0.0389^{\mathrm{a}}$ & 0.0086 \\
$a_{12}$ & $\ln W_{1} \times \ln W_{2}$ & -0.0214 & 0.0305 \\
$a_{13}$ & $\ln W_{1} \times \ln W_{3}$ & 0.0335 & 0.0271 \\
$a_{Q 2}$ & $\ln Q \times \ln W_{2}$ & -0.0068 & 0.0130 \\
$a_{23}$ & $\ln W_{2} \times \ln W_{3}$ & -0.0240 & 0.0279 \\
$a_{Q 3}$ & $\ln Q \times \ln W_{3}$ & 0.0003 & 0.0078 \\
Log-likelihood & & 1021.2181 & \\
Wald Chi-square & & $19,818.07^{\mathrm{a}}$ & \\
Observations & & 900 & \\
Banks & & 151 & \\
\hline$a_{c}$ signficance & &
\end{tabular}

a $, \mathrm{b}, \mathrm{c}$ : significance levels of $1 \%, 5 \%$ and $10 \%$ respectively

\section{Abbreviations}

ES: Economies of scale; GDP: Gross Domestic Product; ICTs: Information \& Communication Technology; QLH: Quiet Life Hypothesis; SSA: Sub-Saharan Africa; UCITS: Transferable Securities Directives; USA: United States of America

\section{Acknowledgements}

The authors are indebted to the editor and reviewers for constructive comments.

\section{Funding}

This is an unfunded paper.

Availability of data and materials

The data for this paper is available upon request.

\section{Authors' contributions}

SAA participated in the writing of the manuscript and data analysis and NMO participated in the revision and proofreading of the manuscript. Both authors read and approved the final manuscript.

\section{Ethics approval and consent to participate}

Not applicable.

\section{Consent for publication}

Not applicable.

\section{Competing interests}

The authors declare that they have no competing interests.

\section{Publisher's Note}

Springer Nature remains neutral with regard to jurisdictional claims in published maps and institutional affiliations. 
Received: 28 February 2018 Accepted: 16 January 2019

Published online: 31 January 2019

\section{References}

Ahokpossi C (2013) Determinants of bank interest margins in Sub-Saharan Africa. In: IMF Working Paper No. 13/34, Washington D.C

Aigner DJ, Chu SF (1968) On estimating the industry production function. Am Econ Rev 58(4):826-839

Allen L, Rai A (1996) Operational efficiency in banking: an international comparison. J Bank Financ 20(4):655-672

Al-Muharrami S, Methews K (2009) Market power versus efficient-structure in Arab GCC banking. Appl Financ Econ 19(18): 1487-1496

Altunbas Y, Liu MH, Molyneux P, Seth RR (2000) Efficiency and risk in Japanese banking. J Bank Financ 24(10):1605-1628

Anginer D, Demirguc-Kunt A, Zhu M (2014) How does competition affect bank systemic risk? J Financ Intermed 23(1):1-26

Ariss RT (2010) On the implications of market power in banking: evidence from developing countries. J Bank Financ 34(4): $765-775$

Asongu S, Bauto M, Nwachukwu J, Tchamyou V (2018a) Is information diffusion a threat to market power for financial access? Insights from the African banking industry. J Multinatl Financ Manag 45(June):88-104

Asongu SA (2013) Investment and inequality in Africa: which financial channels are good for the poor? Afr Financ J 15(2):44-66

Asongu SA (2017) The effect of reducing information asymmetry on loan price and quantity in the African banking industry. Res Int Bus Financ 41(October):185-197

Asongu SA, Biekpe N (2018) ICT, information asymmetry and market power in African banking industry. Res Int Bus Financ 44(April):518-531

Asongu SA, le Roux S (2018) Understanding sub-Saharan Africa's extreme poverty tragedy. Int J Public Adm. https:/doi.org/ $10.1080 / 01900692.2018 .1466900$

Asongu SA, le Roux S, Tchamyou VS (2018b) Essential information sharing thresholds for reducing market power in financial access: a study of the African banking industry. J Bank Regul. https://doi.org/10.1057/s41261-018-0065-4

Asongu SA, Nwachukwu J, Tchamyou VS (2016) Information asymmetry and financial development dynamics in Africa. Rev Dev Financ 6(2):126-138

Asongu SA, Nwachukwu JC (2018) Bank size, information sharing and financial access in Africa. Int J Manag Financ 14(2):188-209

Asongu SA, Odhiambo N (2018) Testing the quiet life hypothesis in the African banking industry. J Ind Compet Trade. https://doi.org/10.1007/s10842-018-0278-3

Battese GE, Coelli TJ (1992) Frontier production function, technical efficiency and panel data with application to Paddy farmers in India. J Prod Anal 3(3-4):153-169

Beck T, Demirgüç-Kunt A, Levine R (1999) A New Database on Financial Development and Structure. In: World Bank Policy Research Working Paper No. 2146, Washington D.C

Beck T, Hesse H (2006) Bank efficiency, ownership and market structure: why are interest spreads so high in Uganda? In: Policy Research Working Paper Series No. 4027, Washington D.C

Berger AN, Hanweck TN, Humphrey DB (1987) Competitive viability in banking: scale, scope and product mix economies. J Monet Econ 20(3):501-520

Berger AN, Mester $\amalg$ (1997) Inside the black box: what explains differences in the efficiencies of financial institutions. J Bank Financ 21(7):895-947

Boadi I, Dana LP, Mertens G, Mensah L (2017) SMEs' financing and banks' profitability: a "good date" for banks in Ghana? J Afr Bus 17(2):257-277

Boateng A, Asongu SA, Akamavi R, Tchamyou VS (2018) Information asymmetry and market power in the African banking industry. J Multinatl Financ Manag 44(March):69-83

Bocher FT, Alemu BA, Kelbore ZG (2017) Does access to credit improve household welfare? Evidence from Ethiopia using endogenous regime switching regression. Afr J Econ Manag Stud 8(1):51-65

Bokpin GA (2016) Bank governance, regulation and risk-taking in Ghana. J Afr Bus 17(1):52-68

Brown R, O'Connor I (1995) Measurement of economies of scale in Victorian credit unions. Aust J Manag 20(1):1-24

Chapoto T, Aboagye AQQ (2017) African innovations in harnessing farmer assets as collateral. Afr J Econ Manag Stud 8(1):66-75

Chester P (2010) Inclusive Growth and Employment in Africa. United Nations Dispatch http://www.undispatch.com/inclusivegrowth-employment-in-africa (accessed: 13 Sept 2013)

Chikalipah S (2017) What determines financial inclusion in sub-Saharan Africa? Afr J Econ Manag Stud 8(1):8-18

Chortareas GE, Garza-Garcia JG, Girardone C (2012) Competition, efficiency and interest rate margins in Latin American banking. Int Rev Financ Anal 24(September):93-103

Christensen LR, Jorgenson DW, Lau LJ (1971) Transcendental logarithmic production Frontiers. Rev Econ Stat 55(1):28-45

Clark J (1996) Economic cost, scale efficiency and competitive viability in banking. J Money Credit Bank 28(3):342-364

Coccorese P (2014) Estimating the Lerner index for the banking industry: a stochastic frontier approach. Appl Financ Econ 24(2):73-88

Coccorese P, Pellecchia A (2010) Testing the 'quiet life' hypothesis in the Italian banking industry. Econ Notes 39(3):173-202

Dabla-Norris E, Floerkemeier H (2007) Bank efficiency and market structure: what determines banking spreads in Armenia? In: IMF Working Paper 07/134, Washington D.C

Daniel A (2017) Introduction to the financial services in Africa special issue. Afr J Econ Manag Stud 8(1):2-7

De Keuleneer E, Leszczynska N (2012) Size in banking: efficiency of scale vs. abuse of power. Global Economic Intersection http://econintersect.com/wordpress/?p=19616 (accessed: 12 Sept 2013)

Delis MD, Tsionas EG (2009) The joint estimation of Bank-level market power and efficiency. J Bank Financ 33(10):1842-1850

Demirgüç-Kunt A, Harry H (2011) Do we need big banks? Evidence on performance, strategy and market discipline. In: Policy Research Working Paper No. 5576, Washington D.C

Fanta AB (2016) Complementarity between relationship lending and collateral in SME access to Bank credit: evidence from Ethiopia. J Afr Bus 17(3):308-318

Farrell MJ (1957) The measurement of productive efficiency. J R Stat Soc 120(3):253-290

Fowowe B (2014) Law and finance revisited: evidence from African countries. S Afr J Econ 82(2):193-208 
Fu X, Heffernan S (2009) The effects of reform on China's Bank structure and performance. J Bank Financ 33(1):39-52

Fukuyama W (1993) Technical and scale efficiency of Japanese commercial banks: a non-parametric approach. Appl Econ 25(8):1101-1112

Goldberg LG, Rai AA (1996) The structure-performance relationship for European banking. J Bank Financ 20(4):745-771

Hamdi H, Hakimi A, Zaghdoudi K (2018) Diversification, bank performance and risk: have Tunisian banks adopted the new business model? Financ Innov 3(22):1-25

Hicks J (1935) Annual survey of economic theory: the theory of monopoly. Econometrica 3(1):1-20

Huang Y, Kou G (2016) A kernel entropy manifold learning approach for financial data analysis. Decis Support Syst 64(2014):31-42

lyke BN, Odiambo NM (2017) Foreign exchange markets and the purchasing power parity theory: evidence from two southern African countries. Afr J Econ Manag Stud 8(1):89-102

Karray SC, Chichti JE (2013) Bank size and efficiency in developing countries: intermediation approach versus value added approach and impact of non-traditional activities. Asian Econ Financ Rev 3(5):593-613

Kashif M, Iftikhar SF, Iftikhar K (2016) Loan growth and bank solvency: evidence from the Pakistan banking sector. Financ Innov 2(22):1-13

Khraisha T, Arthur K (2018) Can we have a general theory of financial innovation processes? A conceptual review. Financ Innov 4(4):1-27

Koetter M, Kolari JW, Spierduk L (2008) Efficient competition ? Testing the 'quiet life' of U. S banks with adjusted Lerner indices. In: Proceedings of the $44^{\text {th }}$ 'Bank structure and competition' conference, Federal Reserve Bank of Chicago

Koetter M, Vins O (2008) The quiet life hypothesis in banking-evidence from German savings banks. In: Department of Finance, Goethe University, Working Paper Series: Finance and Accounting No. 190, Frankfurt

Kumbhakar SC, Baardsen S, Lien G (2012) A new method for estimating market power with an application to Norwegian sawmilling. Rev Ind Organ 40(2):109-129

Kusi BA, Agbloyor EK, Ansah-Adu K, Gyeke-Dako A (2017) Bank credit risk and credit information sharing in Africa: does credit information sharing institutions andcontext matter? Res Int Bus Financ 42(December):1123-1136

Kusi BA, Opoku Mensah M (2018) Does credit information sharing affect funding cost of banks? Evidence from African banks. Int J Financ Econ 23(1):19-28

Lang G, Welzel P (1996) Efficiency and technical progress in banking: empirical results for a panel of German cooperative banks. J Bank Financ 20(6):1003-1023

Maudos J, De Guevara JF (2007) The cost of market power in banking: social welfare loss vs. cost inefficiency. J Bank Financ 31(7):2103-2125

Mester L (1992) Traditional and nontraditional banking: an information-theoretic approach. J Bank Financ 16(3):545-566

Mitchell K, Onvural NM (1996) Economies of scale and scope at large commercial banks: evidence from the Fourier flexible form. J Money Credit Bank 28(2):178-199

Moudud-Ul-Huq S (2017) Performance of banking industry in Bangladesh: insights of CAMEL rating. Int J Financ Eng 4(2):1-15

Muazu I, Alagidede P (2017) Financial development, growth volatility and information asymmetry in sub-Saharan Africa: does law matter? S Afr J Econ 85(4):570-588

Ngigi G (2013a) CBK puts big banks on the spot over high interest rates. Business Daily http://www.businessdailyafrica.com/CBKputs-big-banks-on-the-spot-over-high-interest-rates/-/539552/1908098/-/7t6949z/-/index.html (accessed: 22 July 2013)

Ngigi G (2013b) High cost of loans favours big banks over small lenders. Business Daily http://www.businessdailyafrica.com/ High-cost-of-loans-favours-big-banks-over-small-lenders/-/539552/1744902/-/awkd24/-/index.html (accessed: 22 July 2013)

Noulas AG, Ray SC, Miller SM (1990) Returns to scale and input substitution for large banks. J Money Credit Bank 22(1):94-108

O'brien RM (2007) (2007). "A caution regarding rules of thumb for variance inflation factors". Qual Quant 41:673-690

Obeng SK, Sakyi D (2017) Macroeconomic determinants of interest rate spreads in Ghana. Afr J Econ Manag Stud 8(1):76-88

Ofori-Sasu D, Abor JY, Osei AK (2017) Dividend policy and shareholders' value: evidence from listed companies in Ghana. Afr Dev Rev 29(2):293-304

Osah O, Kyobe M (2017) Predicting user continuance intention towards M-pesa in Kenya. Afr J Econ Manag Stud 8(1):36-50

Ozili PK (2017) Bank profitability and capital regulation: evidence from listed and non-listed banks in Africa. J Afr Bus 18(2):143-168

Pruteanu-Podpiera A, Weill L, Schobert F (2008) Banking competition and efficiency: a micro-data analysis on the Czech banking industry. Comp Econ Stud 50(2):253-273

Ramlall I, Mamode F (2017) A critical assessment of Basel III and its implications on the Mauritian banking sector. J Afr Bus 18(1):70-101

Schaeck K, Cihak M (2008) How does competition affect efficiency and soundness in banking? New empirical evidence. In: ECB Working Paper Series, No. 932, European Central Bank, Frankfurt

Solis L, Maudos J (2008) The social costs of Bank market power: evidence from Mexico. J Comp Econ 36(3):467-488

Srivastava P (1999) Size, efficiency and financial reforms in Indian banking. In: Indian Council for Research on International Economic Relations, Working Paper No. 49, New Delhi

Tchamyou VS (2018a) Education, lifelong learning, inequality and financial access: evidence from African countries. Contemp Soc Sci. https://doi.org/10.1080/21582041.2018.1433314

Tchamyou VS (2018b) The role of information sharing in modulating the effect of financial access on inequality. J Afr Bus.

Tchamyou VS, Asongu SA (2017) Information sharing and financial sector development in Africa. J Afr Bus 18(1):24-49

Tchamyou VS, Asongu SA, Nwachukwu JC (2018) Effects of asymmetric information on market timing in the mutual fund industry. Int J Manag Finance 14(5):542-557

Triki T, Gajigo O (2014) Credit bureaus and registries and access to finance: new evidence from 42 African countries. J Afr Dev 16(2):73-101

Tsionas EG, Milikov E, Kumbhakar SC (2018) An internally consistent approach to the estimation of market power and cost efficiency with an application to U.S. banking. Eur J Oper Res 270(2):747-760

$\mathrm{Tu}$ AH, Chen S (2000) Bank market structure and performance in Taiwan before and after the 1991 liberalization. Rev Pac Basin Financ Mark Policies 3(2000):475-490

Wagenvoort R, Schure P (1999) Economies of scale and efficiency in European banking: new evidence. In: ) (ed) Economic and Financial Reports 1999/1, Economic Investment, European Central Bank, Frankfurt 
Wale LE, Makina D (2017) Account ownership and use of financial services among individuals: evidence from selected sub-Saharan African economies. Afr J Econ Manag Stud 8(1):19-35

Weill L (2004) On the relationship between competition and efficiency in the EU banking sectors. Kredit und Kapital 37(3):329-352

Yan H, Gang K, Yi P (2017) Nonlinear manifold learning for early warnings in financial markets. Eur J Oper Res 258(2):692-702

Zheng C, Gupta AD, Moudud-Ul-Huq S (2017) Do market competition and development indicators matter for banks' risk, capital, and efficiency relationship? Int J Financ Eng 4(2):1-27

Submit your manuscript to a SpringerOpen ${ }^{\odot}$ journal and benefit from:

- Convenient online submission

- Rigorous peer review

- Open access: articles freely available online

- High visibility within the field

- Retaining the copyright to your article

Submit your next manuscript at $\boldsymbol{\nabla}$ springeropen.com 